\title{
Water quality and ecological role of urban lake: a case study of Słoneczne Lake in Szczecin (NW-Poland)
}

\author{
TyMOTEusz Miller, ${ }^{1}$ AleKSANDra DroZDOWSKA, ${ }^{2}$ ANDrZEJ ZAWAL, ${ }^{3}$ \\ GORZYSŁAW POLESZCZUK ${ }^{4}$
}

\footnotetext{
${ }^{1}$ University of Szczecin, Department of Chemistry and Natural Waters Management, Institute for Research on Biodiversity, Faculty of Biology, Poland, e-mail: tymoteusz.miller@usz.edu.pl, ORCID ID: 0000-0002-5962-5334

${ }^{2}$ University of Szczecin, Student science club of research and protection of natural water ecosystems in the city of Szczecin, Faculty of Biology, Poland

${ }^{3}$ University of Szczecin, Department of Invertebrate Zoology and Limnology, Institute for Research on Biodiversity, Faculty of Biology, Poland, e-mail: andrzej.zawal@usz.edu.pl, ORCID ID: 0000-0002-5838-6060

${ }^{4}$ University Szczecin, Department of Chemistry and Natural Waters Management Institute for Research on Biodiversity Faculty of Biology, Poland, e-mail: gorzyslaw.poleszczuk@usz.edu.pl
}

Keywords water quality, urban lake, CA, FA

Abstract This paper presents the differentiation of water quality in urban flowing water reservoir on the example of Słoneczne Lake in Szczecin along the water runway through the lake on a basis of 21 selected water quality indices at intervals of approximately one month. Water quality was determined on the basis of current Legal Acts in Poland. Based on the collected data and the use of chemometric techniques, an attempt was made to determine the role of the Słoneczne Lake in the hydrological network of Szczecin.

\section{Jakość wody i ekologiczna rola jeziora śródmiejskiego na przykładzie Jeziora Słonecznego w Szczecinie (NW-Polska)}

Słowa kluczowe jakość wody, jezioro miejskie, analiza skupień, analiza czynnikowa

Streszczenie $\quad$ W niniejszej pracy przedstawiono zróżnicowanie jakości wody w miejskim przepływowym zbiorniku wodnym na przykładzie Jeziora Słonecznego w Szczecinie wzdłuż drogi spływu wód przez zbiornik wodny, oznaczając 21 wybranych wskaźników jakości wody w odstępach ok. jednomiesięcznych. Określano jakość wody na podstawie obecnie obowiązujących przepisów prawnych w Polsce. Na podstawie zebranych danych i wykorzystaniu technik chemometrycznych podjęto próbę określenia roli, jaką pełni Jezioro Słoneczne w sieci hydrologicznej miasta Szczecina.

\section{Introduction}

Water reservoirs in cities, which are usually flowable, of natural or artificial origin, fulfill a number of important functions in urban agglomerations. First of all - a recreational function, 
because the areas located near the reservoirs are often park areas with walking trails or other recreational functions. At the same time, very often, or indeed always, they are receivers of water from the urban sewage system, in which they act as retention reservoirs, as well as sedimentation ponds and even biological sewage treatment plants. Increase in environmental pollution and constantly emerging new sources of pollution make it necessary to regularly carry out studies aimed at determining the quality of the water in the tanks and the inner-discernment - if changes occur in the quality of the way along the run-off - which biogeohydrochemical processes changes affect their quality. The Słoneczne Lake in Szczecin, located in the Gumieńce district, through which the Bukowa stream flows, is an example of such an urban reservoir (Angyual et al., 2016; Gutches et al., 2016; Hill et al., 2017; Huser et al., 2016; Miller et al., 2016; Olguin et al., 2017; Song et al., 2016).

The purpose of this work was to determine - based on the research conducted in the period from January to June 2015 of the selected water quality indices of the Słoneczne Lake - the quality of the water in this Lake and to determine whether this urban lake acts as a pond for decontamination and biological treatment of waste water - as long as there will be changes in the quality of the water flowing through this reservoir - what biogeohydrochemical processes have caused changes in the quality of water in the reservoir.

\section{Characteristic of Słoneczne Lake}

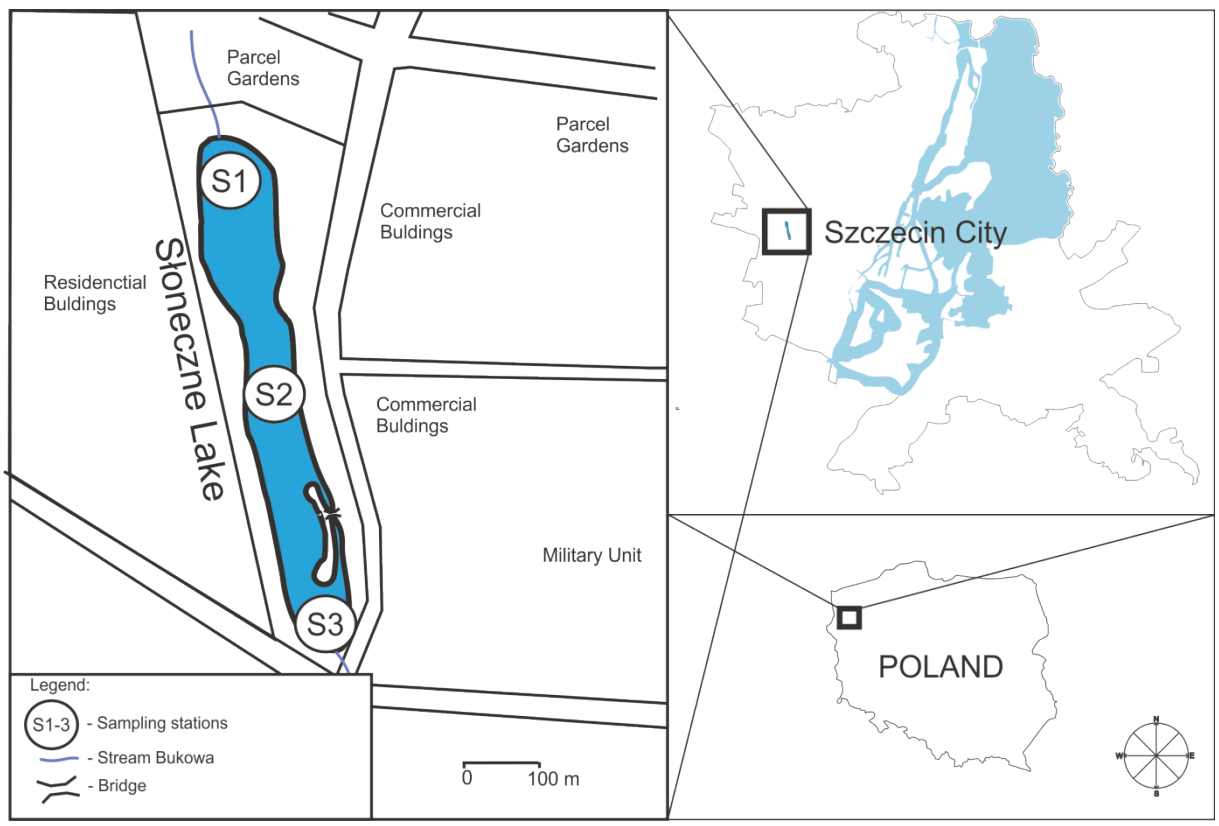

Figure 1. Słoneczne Lake in Szczecin (NW-Poland) 
Słoneczne Lake (Figure 1) is a flowing water reservoir in the western part of the city of Szczecin in the Gumieńce district. It is an artificial reservoir created in the 30s of the last century on the marshy riverbeds adjoining the Bukowa River, during regulation of its runoff road. The Bukowa flows from the Bezrzecze district and is additionally supplied with the waters of Stobnica and Wierzbak. Bukowa river water flows after passing through Słoneczne Lake and further through Szczecin's urban areas - to the Western Odra River (Białecki et al., 1991; Hłyńczak et al., 1998; Niedźwiecki et al., 2007; Tadajewski et al., 1993). The surface of the tank is approx. 4.8 ha. The length is about $1.3 \mathrm{~km}$ and the max depth is almost $2 \mathrm{~m}$. The average retention time - based on surface runoffs - is from 14 to 33 days. Detailed lake morphometric indicators are included in Table 1 (Białecki et al., 1991; Hłyńczak et al., 1998; Niedźwiecki et al., 2007; Tadajewski et al., 1993).

Table 1. Morphometric characteristic of Słoneczne Lake in Szczecin

\begin{tabular}{|l|c|c|}
\hline \multirow{2}{*}{\multicolumn{1}{|c|}{ Geographical coordinates }} & Latitude & $53^{\circ} 25^{\prime} 29^{\prime \prime} \mathrm{N}$ \\
\cline { 2 - 3 } & Longitude & $14^{\circ} 29^{\prime} 54^{\prime \prime} \mathrm{E}$ \\
\hline Morphometric data & \multicolumn{2}{c|}{} \\
\hline Morphometric indicator & Units & Słoneczne Lake \\
\hline Water level & {$[\mathrm{m}$ asl $]$} & 16,9 \\
\hline Area & {$\left[10^{4} \mathrm{~m}^{2}\right]$} & 5,4 \\
\hline Capacity & {$\left[10^{3} \mathrm{~m}^{3}\right]$} & 59,4 \\
\hline Depth - max & {$[\mathrm{m}]$} & 1,3 \\
\hline Depth - average & {$[\mathrm{m}]$} & 1,1 \\
\hline Length max & {$[\mathrm{m}]$} & 640,0 \\
\hline Width max & {$[\mathrm{m}]$} & 90,0 \\
\hline Length of coastline & {$[\mathrm{m}]$} & 1320 \\
\hline
\end{tabular}

\section{Material and methods}

Samples of water for the study were taken from January to June 2015 from a depth of about $25 \mathrm{~cm}$ below the water mirror at a distance of about $2 \mathrm{~m}$ from the shore at the stations indicated in Figure 1, and in particular at the stations: No. 1 (S1) - inflow area of Bukowa River to Słoneczne Lake, station No. 2 (S2) - in the central part of the lake and station No. 3 (S3) - in the area of the outflow of water from the reservoir. Samples were collected on 11.01, 23.02, 22.03, 25.04, 25.05 and 17.06.2015 according to APHA (2012).

The 21 selected water quality indices were determined, in particular: physical parameters such as temperature (TEMP), $\mathrm{pH}$, redox potential (Eh), electrical conductivity of water at $20^{\circ} \mathrm{C}$ (EC) and chemical - chemical oxygen demand (COD-Cr, COD-Mn), dissolved oxygen (DO) water saturation by $\mathrm{O}_{2}$ (WS), concentrations of $\mathrm{NO}_{3}{ }^{-}, \mathrm{NO}_{2}{ }^{-}, \mathrm{NH}_{4}{ }^{+}, \mathrm{PO}_{4}{ }^{3-}$ (soluble reactive orthophosphates (V) - SRP), total nitrogen (TN) and phosphorus, concentrations of $\mathrm{Ca}^{2+}, \mathrm{Cl}^{-}, \mathrm{SO}_{4}{ }^{2-}$, general hardness $(\mathrm{TH})$, general alkalinity $(\mathrm{Alk})$ and total concentration of iron $\left(\mathrm{Fe}_{\mathrm{tot}}\right)$. All analysis, storage and transport of samples for testing were performed as recommended by APHA (2012). 


\section{Chemometric procedures}

The results of the research on the quality parameters of the solar lake were analyzed using selected chemometric procedures and in particular the cluster analysis (CA), Spearman coefficients were calculated between successive water quality indices and the factor analysis (FA). The CA method was used to detect and visualize the similarities and differences between the variability of individual water quality indices, examining the nature of variations for different sampling sites (station numbers) and individual sampling dates

Table 2. Statistical characteristics of selected water quality indices on all sampling stations in the period from January to June in 2015 year

\begin{tabular}{|c|c|c|c|c|c|}
\hline Detail & Units & $\begin{array}{c}\text { Descriptive } \\
\text { statistics }\end{array}$ & S1 & S2 & S3 \\
\hline 1 & 2 & 3 & 4 & 5 & 6 \\
\hline Temperature & ${ }^{\circ} \mathrm{C}$ & $\begin{array}{l}\text { Mean } \pm \text { SD } \\
\text { Range } \\
\text { CV }\end{array}$ & $\begin{array}{c}10.8 \pm 6.6 \\
3.9-20.1 \\
0.61\end{array}$ & $\begin{array}{c}11.0 \pm 8.7 \\
1.2-22.0 \\
0.79\end{array}$ & $\begin{array}{c}10.9 \pm 8.2 \\
1.4-21.0 \\
0.75\end{array}$ \\
\hline $\mathrm{pH}$ & jedn. $\mathrm{pH}$ & $\begin{array}{l}\text { Mean } \pm \text { SD } \\
\text { Range } \\
\text { CV }\end{array}$ & $\begin{array}{c}7.50 \pm 0.31 \\
7.11-7.77 \\
0.04\end{array}$ & $\begin{array}{c}7.59 \pm 0.45 \\
7.03-8.12 \\
0.06\end{array}$ & $\begin{array}{c}7.63 \pm 0.42 \\
7.16-8.17 \\
0.05\end{array}$ \\
\hline $\mathrm{EC}$ & $\mu \mathrm{S} \cdot \mathrm{cm}^{-1}$ & $\begin{array}{l}\text { Mean } \pm \text { SD } \\
\text { Range } \\
\text { CV }\end{array}$ & $\begin{array}{c}729 \pm 248 \\
393-1031 \\
0.34\end{array}$ & $\begin{array}{c}625 \pm 128 \\
453-768 \\
0.20\end{array}$ & $\begin{array}{c}604 \pm 170 \\
329-787 \\
0.28\end{array}$ \\
\hline Eh & $\mathrm{mV}$ & $\begin{array}{l}\text { Mean } \pm \text { SD } \\
\text { Range } \\
\text { CV }\end{array}$ & $\begin{array}{c}448 \pm 12 \\
429-458 \\
0.03\end{array}$ & $\begin{array}{c}453 \pm 17 \\
434-480 \\
0.04 \\
\end{array}$ & $\begin{array}{c}448 \pm 27 \\
407-490 \\
0.06\end{array}$ \\
\hline COD-Mn & $\mathrm{mg} \mathrm{O}_{2} \cdot \mathrm{dm}^{-3}$ & $\begin{array}{l}\text { Mean } \pm \text { SD } \\
\text { Range } \\
\text { CV }\end{array}$ & $\begin{array}{c}11.9 \pm 1.2 \\
11.1-14.2 \\
0.10\end{array}$ & $\begin{array}{c}11.2 \pm 1.1 \\
10.4-13.5 \\
0.10\end{array}$ & $\begin{array}{c}11.1 \pm 1.0 \\
10.2-13.0 \\
0.09\end{array}$ \\
\hline $\mathrm{COD}-\mathrm{Cr}$ & $\mathrm{mg} \mathrm{O}_{2} \cdot \mathrm{dm}^{-3}$ & $\begin{array}{l}\text { Mean } \pm \text { SD } \\
\text { Range } \\
\text { CV }\end{array}$ & $\begin{array}{c}303.0 \pm 141.6 \\
150.0-573.0 \\
0.47\end{array}$ & $\begin{array}{c}79.7 \pm 32.7 \\
52.0-135.0 \\
0.41 \\
\end{array}$ & $\begin{array}{c}66.4 \pm 19.4 \\
40.0-93.0 \\
0.29 \\
\end{array}$ \\
\hline $\mathrm{BOD}_{5}$ & $\mathrm{mg} \mathrm{O}_{2} \cdot \mathrm{dm}^{-3}$ & $\begin{array}{l}\text { Mean } \pm \text { SD } \\
\text { Range } \\
\text { CV }\end{array}$ & $\begin{array}{c}7.7 \pm 2.3 \\
5.0-10.0 \\
0.29\end{array}$ & $\begin{array}{c}5.3 \pm 0.8 \\
4.0-6.0 \\
0.15\end{array}$ & $\begin{array}{c}4.7 \pm 1.4 \\
3.0-7.0 \\
0.29 \\
\end{array}$ \\
\hline DO & $\mathrm{mg} \mathrm{O}_{2} \cdot \mathrm{dm}^{-3}$ & $\begin{array}{l}\text { Mean } \pm \text { SD } \\
\text { Range } \\
\text { CV }\end{array}$ & $\begin{array}{c}10.2 \pm 4.4 \\
6.0-18.0 \\
0.43\end{array}$ & $\begin{array}{c}13.3 \pm 4.5 \\
8.0-20.0 \\
0.34\end{array}$ & $\begin{array}{c}12.8 \pm 3.7 \\
9.0-19.0 \\
0.29\end{array}$ \\
\hline WS & $\%$ & $\begin{array}{l}\text { Mean } \pm \text { SD } \\
\text { Range } \\
\text { CV }\end{array}$ & $\begin{array}{c}88.1 \pm 26.8 \\
65.4-137.0 \\
0.30 \\
\end{array}$ & $\begin{array}{c}114.3+18.2 \\
90.4-141.2 \\
0.16 \\
\end{array}$ & $\begin{array}{c}110.8 \pm 12.4 \\
99.8-134.9 \\
0.11 \\
\end{array}$ \\
\hline $\mathrm{NO}_{3}^{-}$ & $\mathrm{mg} \mathrm{N}-\mathrm{NO}_{3} \cdot \mathrm{dm}^{-3}$ & $\begin{array}{l}\text { Mean } \pm \text { SD } \\
\text { Range } \\
\text { CV }\end{array}$ & $\begin{array}{c}1.37 \pm 0.37 \\
1.01-1.97 \\
0.27\end{array}$ & $\begin{array}{c}0.91 \pm 0.21 \\
0.63-1.23 \\
0.23\end{array}$ & $\begin{array}{c}0.86 \pm 0.22 \\
0.60-1.15 \\
0.25\end{array}$ \\
\hline $\mathrm{NO}_{2}^{-}$ & $\mathrm{mg} \mathrm{N}-\mathrm{NO}_{2} \cdot \mathrm{dm}^{-3}$ & $\begin{array}{l}\text { Mean } \pm \text { SD } \\
\text { Range } \\
\text { CV }\end{array}$ & $\begin{array}{c}0.147 \pm 0.137 \\
0.040-0.400 \\
0.93\end{array}$ & $\begin{array}{c}0.052 \pm 0.057 \\
0.009-0.130 \\
1.09\end{array}$ & $\begin{array}{c}0.064 \pm 0.054 \\
0.004-0.130 \\
0.84\end{array}$ \\
\hline
\end{tabular}




\begin{tabular}{|c|c|c|c|c|c|}
\hline 1 & 2 & 3 & 4 & 5 & 6 \\
\hline $\mathrm{NH}_{4}^{+}$ & $\mathrm{mg} \mathrm{N}-\mathrm{NH}_{4} \cdot \mathrm{dm}^{-3}$ & $\begin{array}{l}\text { Mean } \pm \text { SD } \\
\text { Range } \\
\text { CV }\end{array}$ & $\begin{array}{c}1.23 \pm 0.48 \\
0.71-1.95 \\
0.39\end{array}$ & $\begin{array}{c}0.63 \pm 0.09 \\
0.53-0.78 \\
0.14\end{array}$ & $\begin{array}{c}0.45 \pm 0.15 \\
0.29-0.70 \\
0.33\end{array}$ \\
\hline $\mathrm{TN}$ & $\mathrm{mg} \mathrm{N} \cdot \mathrm{dm}^{-3}$ & $\begin{array}{l}\text { Mean } \pm \text { SD } \\
\text { Range } \\
\text { CV }\end{array}$ & $\begin{array}{c}3.580 .53 \\
2.70-4.21 \\
0.15\end{array}$ & $\begin{array}{c}1.72 \pm 0.58 \\
1.00-2.50 \\
0.34\end{array}$ & $\begin{array}{c}1.56 \pm 0.43 \\
1.11-2.30 \\
0.28\end{array}$ \\
\hline SRP & $\mathrm{mg} \mathrm{P}-\mathrm{PO}_{4} \cdot \mathrm{dm}^{-3}$ & $\begin{array}{l}\text { Mean } \pm \text { SD } \\
\text { Range } \\
\text { CV }\end{array}$ & $\begin{array}{c}0.37 \pm 0.24 \\
0.08-0.68 \\
0.65\end{array}$ & $\begin{array}{c}0.36 \pm 0.21 \\
0.10-0.63 \\
0.58\end{array}$ & $\begin{array}{c}0.37 \pm 0.18 \\
0.19-0.60 \\
0.48\end{array}$ \\
\hline TP & $\mathrm{mg} \mathrm{P}-\mathrm{PO}_{4} \cdot \mathrm{dm}^{-3}$ & $\begin{array}{l}\text { Mean } \pm \text { SD } \\
\text { Range } \\
\text { CV }\end{array}$ & $\begin{array}{c}1.02 \pm 0.54 \\
0.35-1.68 \\
0.53\end{array}$ & $\begin{array}{c}1.04 \pm 0.53 \\
0.47-1.68 \\
0.51\end{array}$ & $\begin{array}{c}1.04 \pm 0.53 \\
0.46-1.70 \\
0.51\end{array}$ \\
\hline $\mathrm{TH}$ & $\mathrm{mg} \mathrm{CaCO}{ }_{3} \cdot \mathrm{dm}^{-3}$ & $\begin{array}{l}\text { Mean } \pm \text { SD } \\
\text { Range } \\
\text { CV }\end{array}$ & $\begin{array}{c}269 \pm 123 \\
124-437 \\
0.46\end{array}$ & $\begin{array}{c}215 \pm 52 \\
183-321 \\
0.24\end{array}$ & $\begin{array}{c}196 \pm 75 \\
112-337 \\
0.38\end{array}$ \\
\hline $\mathrm{Ca}^{2+}$ & $\mathrm{mg} \mathrm{Ca} \cdot \mathrm{dm}^{-3}$ & $\begin{array}{l}\text { Mean } \pm \text { SD } \\
\text { Range } \\
\text { CV }\end{array}$ & $\begin{array}{c}83 \pm 36 \\
387-136 \\
0.43\end{array}$ & $\begin{array}{c}6 \pm 7 \\
57-76 \\
0.10\end{array}$ & $\begin{array}{c}96 \pm 73 \\
62-112 \\
0.76\end{array}$ \\
\hline $\mathrm{Cl}^{-}$ & $\mathrm{mg} \mathrm{Cl} \cdot \mathrm{dm}^{-3}$ & $\begin{array}{l}\text { Mean } \pm \text { SD } \\
\text { Range } \\
\text { CV }\end{array}$ & $\begin{array}{c}50 \pm 26 \\
28-86 \\
0.52 \\
\end{array}$ & $\begin{array}{c}50 \pm 22 \\
27-81 \\
0.44\end{array}$ & $\begin{array}{c}52 \pm 27 \\
28-98 \\
0.51 \\
\end{array}$ \\
\hline $\mathrm{SO}_{4}{ }^{2-}$ & $\mathrm{mg} \mathrm{SO}_{4} \cdot \mathrm{dm}^{-3}$ & $\begin{array}{l}\text { Mean } \pm \text { SD } \\
\text { Range } \\
\text { CV }\end{array}$ & $\begin{array}{c}60 \pm 13 \\
46-80 \\
0.22 \\
\end{array}$ & $\begin{array}{c}58 \pm 13 \\
44-78 \\
0.22\end{array}$ & $\begin{array}{c}57 \pm 13 \\
43-77 \\
0.23 \\
\end{array}$ \\
\hline Alkalinity & mmoli $\mathrm{HCl} \cdot \mathrm{dm}^{-3}$ & $\begin{array}{l}\text { Mean } \pm \text { SD } \\
\text { Range } \\
\text { CV }\end{array}$ & $\begin{array}{c}3.72 \pm 1.47 \\
1.70-5.00 \\
0.39\end{array}$ & $\begin{array}{c}3.82 \pm 1.51 \\
1.60-5.50 \\
0.40\end{array}$ & $\begin{array}{c}3.75 \pm 1.68 \\
1.40-5.60 \\
0.45\end{array}$ \\
\hline $\mathrm{Fe}_{\text {tot }}$ & $\mathrm{mg} \mathrm{Fe} \cdot \mathrm{dm}^{-3}$ & $\begin{array}{l}\text { Mean } \pm \text { SD } \\
\text { Range } \\
\text { CV }\end{array}$ & $\begin{array}{c}0.29 \pm 0.21 \\
0.07-0.62 \\
0.72\end{array}$ & $\begin{array}{c}0.12 \pm 0.17 \\
0.01-0.45 \\
1.41 \\
\end{array}$ & $\begin{array}{c}0.17 \pm 0.17 \\
0.05-0.51 \\
1.00\end{array}$ \\
\hline
\end{tabular}

(sampling dates) and to compare the variability of all identified water quality indices in relation to each other.

The Ward method was used to determine the distance between the clusters - equal squares of the Euclidean distance (Badillo-Camacho et al., 2015; Li et al. 2015; Kari et al., 2009; Mustapha et al., 2013; Miller et al., 2016; Najar et al., 2012). The calculation of Spearman correlation coefficients was to determine the relationship between the water quality indexes so as to distinguish independent indices that characterize water quality changes during the research period. Factor analysis (FA) was used to determine which water quality indices could show the hidden dependencies between its own variability and significant changes in water quality (Affum et al., 2015; Kumar et al., 2014; Kumarasamy et al., 2014; Longanathan et al., 2015; Miller et al., 2016; Wang et al., 2013).

Prior to statistical analysis, standardization of measurement data was carried out to avoid discrepancies between different units of individual water quality indices. To test the usage of collected data for multivariate statistical techniques, the Kaiser-Meyer-Olkin measure of sample 
adequacy test was performed and Bartlett's test of sphericity was performed (Chow et al., 2016; Gao et al., 2015; Taoufim et al., 2017; Singh et al., 2016).

Statistica 12.0 PL and Statgraphics Centurion XVII software were used for the calculations.

\section{Results}

Results of the 21 selected water quality indices of the Słoneczne Lake in period January July 2015 are presented in Table 2 and in the graphs (Figures 2-3), where water quality indicators for all three measurement stations and all sampling dates were compiled.

Water temperature changes in the reservoir during the study period were typical for the lake ecosystem with significant water retention in the temperate zone, where the gradual rise in temperature occurs along with seasons. The $\mathrm{pH}$ of the waters of the Słoneczne Lake fluctuated slightly in particular months. The results of the electric conductivity (EC), as measured during the study period, also changed slightly, remaining stable at all measuring stations at all sampling terms. The value of the oxidation-reduction potential (Eh) index was high and varied slightly between $450-490 \mathrm{mV}$.

Concentration of organic compounds in water characterized by COD-Cr, COD-Mn, and $\mathrm{BOD}_{5}$ had relatively high values, decreasing progressively with the movement of the lake waters towards the drain zone. Results of dissolved oxygen concentration showed a relatively high degree of oxygenation of water. In turn, the values of concentrations of biogenic substances in the waters of the Słoneczne Lake were very diverse. The values of nitrate (V), which were highest in the inflow area of the Bukowa River and were decreasing as the water flowed into the outflow zone from the reservoir, was remarkably changed. Nitrate (III) concentrations generally had stabilized values. Concentrations of ammonium ions and total nitrogen in the studied waters decreased as the water flowed through the lake. Conversely, the concentration of total and soluble reactive orthophosphates (V), whose concentration increased as water flowed through the reservoir, was reversed. Total hardness reached the highest values in the area of inflow zone of Bukowa River. Occasionally, the concentration of calcium ions changed, increasing to more than $100 \mathrm{mg} \mathrm{Ca} \cdot \mathrm{dm}^{-3}$. Typically, the value of this indices did not exceed $80 \mathrm{mg} \mathrm{Ca} \cdot \mathrm{dm}^{-3} \cdot \mathrm{Cl}^{-}$concentrations were usually low, which gradually decreased during the period from January to June. The concentration of $\mathrm{SO}_{4}{ }^{2-}$ in the waters of the Słoneczne Lake was relatively low and stabilized. Total alkalinity values generally were above $3.75 \mathrm{mmol} \mathrm{HCl} \cdot \mathrm{dm}^{-3}$. Total iron concentrations were always very low.

\section{Discussion}

\section{Assessment of the Słoneczne Lake water quality according to currently valid Polish criteria for assessing the quality of lake waters}

In Table 3 shows the classification of the tested waters currently binding in Poland (Regulation, 2016) criteria for assessing the quality of lake water. From the data presented, it is clear that the assessment of water quality based only on physical and chemical indices should be made only on the basis of electrical conductivity in $20^{\circ} \mathrm{C}$, dissolved oxygen, total concentrations of nitrogen and phosphorus among the indices investigated in this paper. From the presented data it is clear that the lowest quality had waters at the S1 station (the zone of water inflow to the lake), where water - actually regardless of the time - were III and lower class water (criteria for III, IV and V 

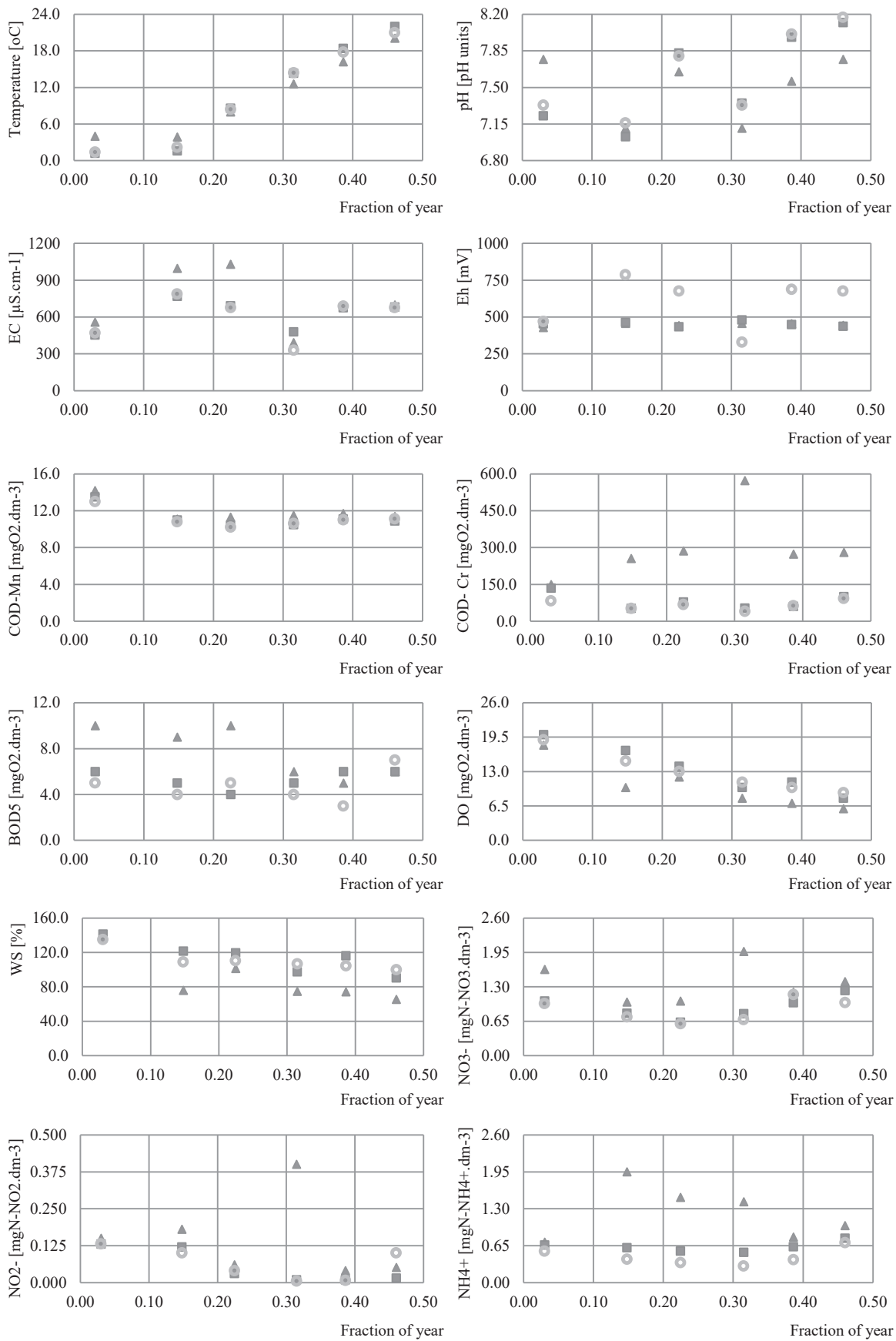

$\boldsymbol{\Delta}$ - inflow area, $\boldsymbol{-}$ - middle of the Lake, o - outflow area.

Figure 2. Changes in selected water quality indices in Słoneczne Lake in 2015 year 

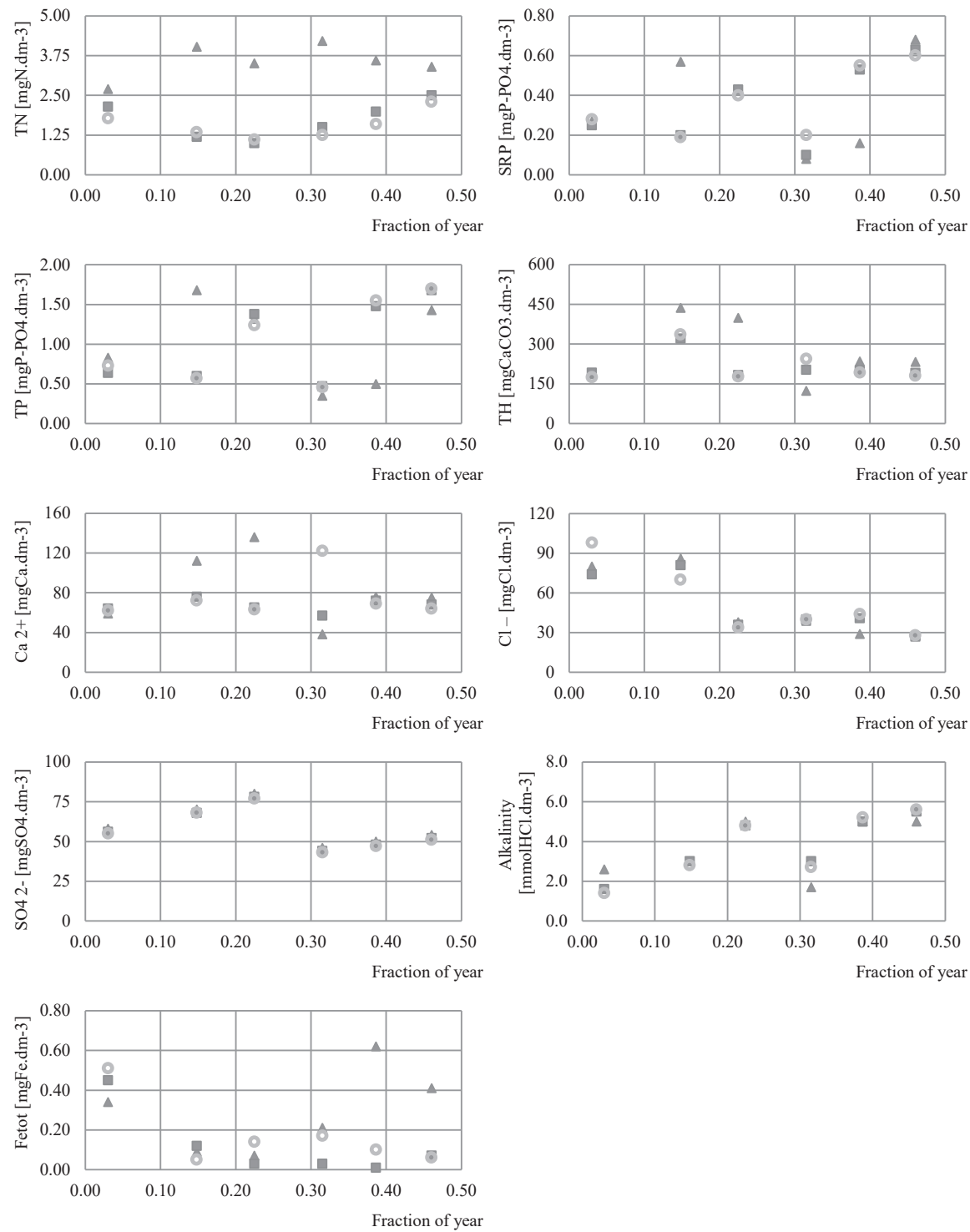

$\boldsymbol{\Delta}$ - inflow area, $\boldsymbol{-}$ - middle of the Lake, ○- outflow area.

Figure 3. Changes in selected water quality indices in Słoneczne Lake in 2015 year 
are not given in the Regulation). Out of the criteria indicating a very low class of water quality, the indices were: the total nitrogen concentration and the total concentration of phosphorus, and also during the melting snow waters inflow - electric conductivity of water. Dissolved oxygen concentrations generally corresponded to I and II water quality classes, as were the other stations.

Table 3. Classification of water quality based on selected water quality indices of Słoneczne Lake during study period from January to July (according to Regulation 2016 J.L. of 2016, item 1187)

\begin{tabular}{|c|c|c|c|c|c|c|c|c|c|c|c|c|c|c|c|c|c|c|c|}
\hline \multirow{3}{*}{ No. } & \multirow{3}{*}{ Indices } & \multicolumn{18}{|c|}{ Water Quality Class } \\
\hline & & \multicolumn{3}{|c|}{$\mathrm{T} 1$} & \multicolumn{3}{|c|}{$\mathrm{T} 2$} & \multicolumn{3}{|c|}{ T3 } & \multicolumn{3}{|c|}{$\mathrm{T} 4$} & \multicolumn{3}{|c|}{ T5 } & \multicolumn{3}{|c|}{ T6 } \\
\hline & & S1 & $\mathrm{S} 2$ & S3 & S1 & S2 & S3 & S1 & $\mathrm{S} 2$ & S3 & S1 & S2 & S3 & S1 & S2 & S3 & S1 & S2 & S3 \\
\hline 1 & Temp $^{1)}$ & - & - & - & - & - & - & - & - & - & - & - & - & - & - & - & - & - & - \\
\hline 2 & $\mathrm{pH}^{1)}$ & - & - & - & - & - & - & - & - & - & - & - & - & - & - & - & - & - & - \\
\hline 3 & EC & $\mathrm{I}, \mathrm{II}^{\mathrm{A}}$ & $\mathrm{I}, \mathrm{II}^{\mathrm{A}}$ & $\mathrm{I}, \mathrm{II}^{\mathrm{A}}$ & $\leq \mathrm{III}^{3)}$ & $\mathrm{I}, \mathrm{II}^{\mathrm{A}}$ & $\mathrm{I}, \mathrm{II}^{\mathrm{A}}$ & $\leq \mathrm{III}^{3)}$ & $\mathrm{I}, \mathrm{II}^{\mathrm{A}}$ & $\mathrm{I}, \mathrm{II}^{\mathrm{A}}$ & $\mathrm{I}, \mathrm{II}^{\mathrm{A}}$ & $\mathrm{I}, \mathrm{II}^{\mathrm{A}}$ & $\mathrm{I}, \mathrm{II}^{\mathrm{A}}$ & $\mathrm{I}, \mathrm{II}^{\mathrm{A}}$ & $\mathrm{I}, \mathrm{II}^{\mathrm{A}}$ & $\mathrm{I}, \mathrm{II}^{\mathrm{A}}$ & $\mathrm{I}, \mathrm{II}^{\mathrm{A}}$ & $\mathrm{I}, \mathrm{II}^{\mathrm{A}}$ & $\mathrm{I}, \mathrm{II}^{\mathrm{A}}$ \\
\hline 4 & $\mathrm{Eh}^{1)}$ & - & - & - & - & - & - & - & - & - & - & - & - & - & - & - & - & - & - \\
\hline 5 & COD-Mn ${ }^{1)}$ & - & - & - & - & - & - & - & - & - & - & - & - & - & - & - & - & - & - \\
\hline 6 & COD-Cr ${ }^{1)}$ & - & - & - & - & - & - & - & - & - & - & - & - & - & - & - & - & - & - \\
\hline 7 & $\mathrm{BOD}^{1)}$ & - & - & - & - & - & - & - & - & - & - & - & - & - & - & - & - & - & - \\
\hline 8 & DO & $\mathrm{I}, \mathrm{II}^{\mathrm{A}}$ & $\mathrm{I}, \mathrm{II}^{\mathrm{A}}$ & $\mathrm{I}, \mathrm{II}^{\mathrm{A}}$ & $\mathrm{I}, \mathrm{II}^{\mathrm{A}}$ & $\mathrm{I}, \mathrm{II}^{\mathrm{A}}$ & $\mathrm{I}, \mathrm{II}^{\mathrm{A}}$ & $\mathrm{I}, \mathrm{II}^{\mathrm{A}}$ & $\mathrm{I}, \mathrm{II}^{\mathrm{A}}$ & $\mathrm{I}, \mathrm{II}^{\mathrm{A}}$ & $\mathrm{I}, \mathrm{II}^{\mathrm{A}}$ & $\mathrm{I}, \mathrm{II}^{\mathrm{A}}$ & $\mathrm{I}, \mathrm{II}^{\mathrm{A}}$ & $\mathrm{I}, \mathrm{II}^{\mathrm{A}}$ & $\mathrm{I}, \mathrm{II}^{\mathrm{A}}$ & $\mathrm{I}, \mathrm{II}^{\mathrm{A}}$ & $\mathrm{I}, \mathrm{II}^{\mathrm{A}}$ & $\mathrm{I}, \mathrm{II}^{\mathrm{A}}$ & $\mathrm{I}, \mathrm{II}^{\mathrm{A}}$ \\
\hline 9 & $\mathrm{WS}^{2)}$ & - & - & - & - & - & - & - & - & - & - & - & - & - & - & - & - & - & - \\
\hline 10 & $\mathrm{NO}_{3}{ }^{-1)}$ & - & - & - & - & - & - & - & - & - & - & - & - & - & - & - & - & - & - \\
\hline 11 & $\mathrm{NO}_{2}{ }^{-1)}$ & - & - & - & - & - & - & - & - & - & - & - & - & - & - & - & - & - & - \\
\hline 12 & $\mathrm{NH}_{4}^{+1)}$ & - & - & - & - & - & - & - & - & - & - & - & - & - & - & - & - & - & - \\
\hline 13 & TN & $\leq \mathrm{III}^{3)}$ & $\leq \mathrm{III}^{3)}$ & $\mathrm{I}, \mathrm{II}^{\mathrm{A}}$ & $\leq \mathrm{III}^{3)}$ & $\mathrm{I}, \mathrm{II}^{\mathrm{A}}$ & $\mathrm{I}, \mathrm{II}^{\mathrm{A}}$ & $\leq \mathrm{III}^{3)}$ & $\mathrm{I}, \mathrm{II}^{\mathrm{A}}$ & $\mathrm{I}, \mathrm{II}^{\mathrm{A}}$ & $\leq \mathrm{III}^{3)}$ & $\mathrm{I}, \mathrm{II}^{\mathrm{A}}$ & $\mathrm{I}, \mathrm{II}^{\mathrm{A}}$ & $\leq \mathrm{III}^{3)}$ & $\mathrm{I}, \mathrm{II}^{\mathrm{A}}$ & $\mathrm{I}, \mathrm{II}^{\mathrm{A}}$ & $\leq \mathrm{III}^{3)}$ & $\leq \mathrm{III}^{3)}$ & $\leq \mathrm{III}^{3)}$ \\
\hline 14 & SRP ${ }^{1)}$ & - & - & - & - & - & - & - & - & - & - & - & - & - & - & - & - & - & - \\
\hline 15 & $\mathrm{TP}^{1)}$ & $\leq \mathrm{III}^{3)}$ & $\leq \mathrm{III}^{3)}$ & $\leq \mathrm{III}^{3)}$ & $\leq \mathrm{III}^{3)}$ & $\leq \mathrm{III}^{3)}$ & $\leq \mathrm{III}^{3)}$ & $\leq \mathrm{III}^{3)}$ & $\leq \mathrm{III}^{3)}$ & $\leq \mathrm{III}^{3)}$ & II & $\leq \mathrm{III}^{3)}$ & II & $\leq \mathrm{III}^{3)}$ & $\leq \mathrm{III}^{3)}$ & $\leq \mathrm{III}^{3)}$ & $\leq \mathrm{III}^{3)}$ & $\leq \mathrm{III}^{3)}$ & $\leq \mathrm{III}^{3)}$ \\
\hline 16 & $\mathrm{TH}^{1)}$ & - & - & - & - & - & - & - & - & - & - & - & - & - & - & - & - & - & - \\
\hline 17 & $\mathrm{Ca}^{2+1)}$ & - & - & - & - & - & - & - & - & - & - & - & - & - & - & - & - & - & - \\
\hline 18 & $\mathrm{Cl}^{-1)}$ & - & - & - & - & - & - & - & - & - & - & - & - & - & - & - & - & - & - \\
\hline 19 & $\mathrm{SO}_{4}^{2-1)}$ & - & - & - & - & - & - & - & - & - & - & - & - & - & - & - & - & - & - \\
\hline 20 & Alkalinity ${ }^{1)}$ & - & - & - & - & - & - & - & - & - & - & - & - & - & - & - & - & - & - \\
\hline 21 & $\mathrm{Fe}_{\text {tot }}{ }^{1)}$ & - & - & - & - & - & - & - & - & - & - & - & - & - & - & - & - & - & - \\
\hline
\end{tabular}

A Water quality limit value common for I and II water quality class

1) water quality indices not included in w Regulation of the Minister of the Environment of 21 July 2016 On how to classify the state of surface water bodies and environmental standards of priority substances (J.L. of 2016 item, 1187)

2) Water quality parameters included in the above. Regulation but not applicable to the classification of lakes of type $3 \mathrm{~b}$

3) For class below II water quality class - the limits not determined

From the compiled data it shows that the water in the Słoneczne lake flowing from inflow area gradually improved its quality, which concerns in particular the total nitrogen concentrations and total phosphorus (in a small extent). In general it can be stated that the indices that "disqualified" tested waters during the research period was the total phosphorus, which concentrations in the waters of the Słoneczne Lake were always very high at all sampling stations in the whole research period. 


\section{Biogehydrogchemical processes occurring in the Słoneczne Lake ekosystem}

Based on data presented in Tables 2-3 and Figures 2-6, it can be concluded that the quality of water flowing from the Bukowa River inflow area to the Słoneczne Lake to the outflow area of the lake has changed considerably. In particular, such indicators as $\mathrm{pH}, \mathrm{Eh}, \mathrm{COD}-\mathrm{Cr}, \mathrm{TN}, \mathrm{NO}_{3}{ }^{-}$and $\mathrm{NH}_{4}^{+}$. These changes have shown a gradual improvement in the quality of the water as it flows towards the outlet of the drainage channels from the reservoir. Particularly clear are the changes between the station No. 1 (area of the water inflow) and the station No. 2 (center of the lake). At this point, the concentration of organic matter in the tank was clearly reduced with a drop in value of COD-Cr, TP, $\mathrm{BOD}_{5}, \mathrm{NO}_{3}^{-}, \mathrm{NH}_{4}{ }^{+}$, connected with a decrease in total hardness, total alkalinity and additionally simultaneously with the increase in concentration of dissolved phosphorus and reactive orthophosphate - although this effect was less clear. This clearly demonstrates that between the stations S1 and S2 sedimentation of the suspensions took place - independently of the time of the sampling. Also on the way from station No. 1 to station No. 2 increased the oxygenation of water. At the same time, the increase in the redox potential (Eh) of the Słoneczne Lake waters was noticeable on the flow from Station 2 to Station 3. All of the above mentioned indices were correlated respectively, as is evident in Table 4.

Very well it is documented also on Figure 4, where the dendrogram showing the similarities and differences of variation of determined water quality parameters. At the same time, the similarity of variability is specifically varied. This is illustrated in Figure 5, showing variation in the variability of the indicators at stations S1 and S2, showing that the greatest variation in the waters of Słoneczne Lake was between S1 and S2. Then the quality of water between the S2 and S3 stations has changed slightly.

Very specifically, the variability of water quality is shown in Figure 6. It follows that the particular similarity of water quality variability was marked by February and March and February and June - which is completely understandable due to climate change. Water quality in the month of January - probably by low temperatures - changed completely.

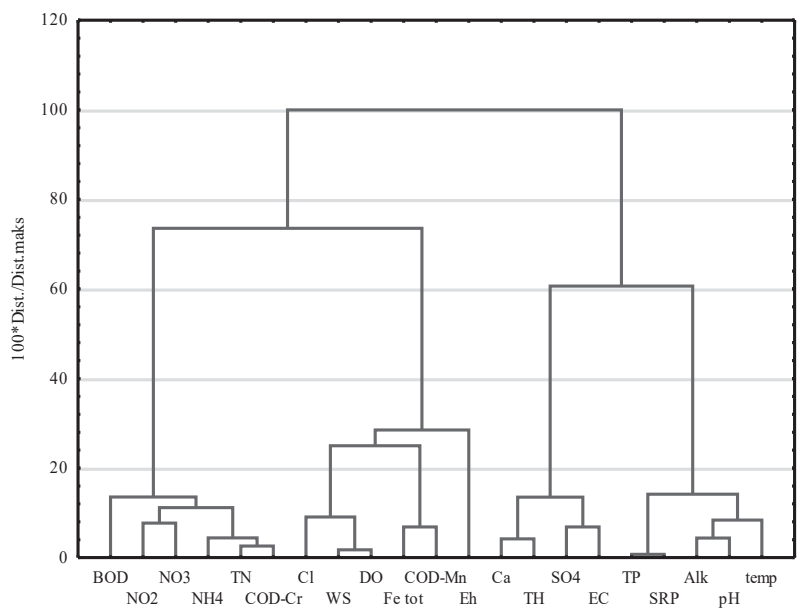

Figure 4. Similarities and differences in variation of selected water quality indices 


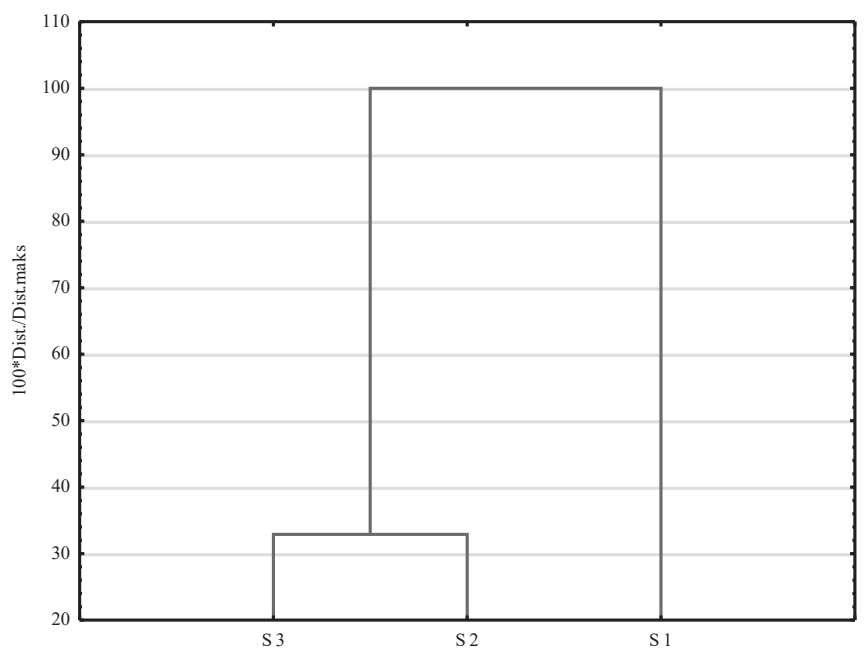

Figure 5. Differentiation of the quality of the waters of the Słoneczne Lake during the research period in the sampling stations

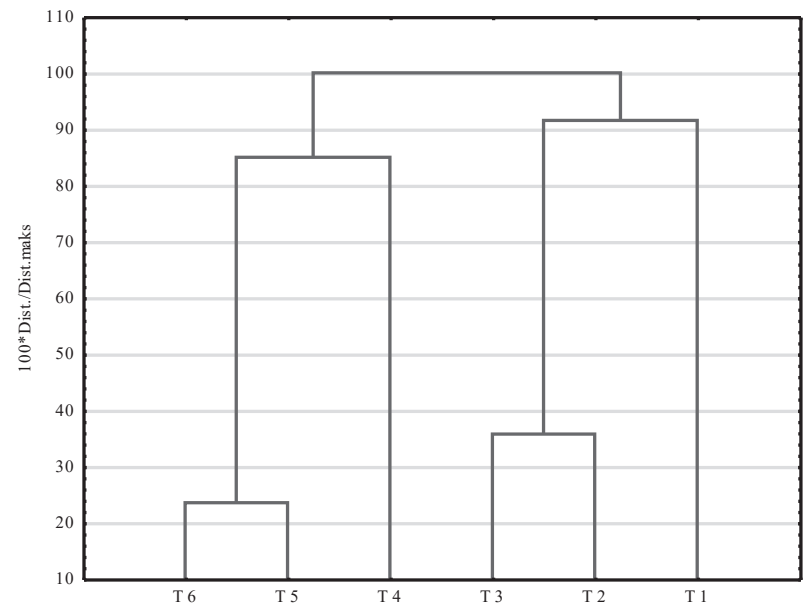

Figure 6. Differentiation of the water quality of the Słoneczne Lake during the study period from January to June 2015 in subsequent months from $\mathrm{T} 1$ to $\mathrm{T} 6$

Otherwise, as in the month of April, which is a "transitional" month between winter and warmer seasons. Very specific changes in the redox potential that occurred between S2 and S3 stations, which do not coincide with changes in oxygenation of water, can be easily explained on the basis of knowledge about redox potential measurements since the redox potential in the 


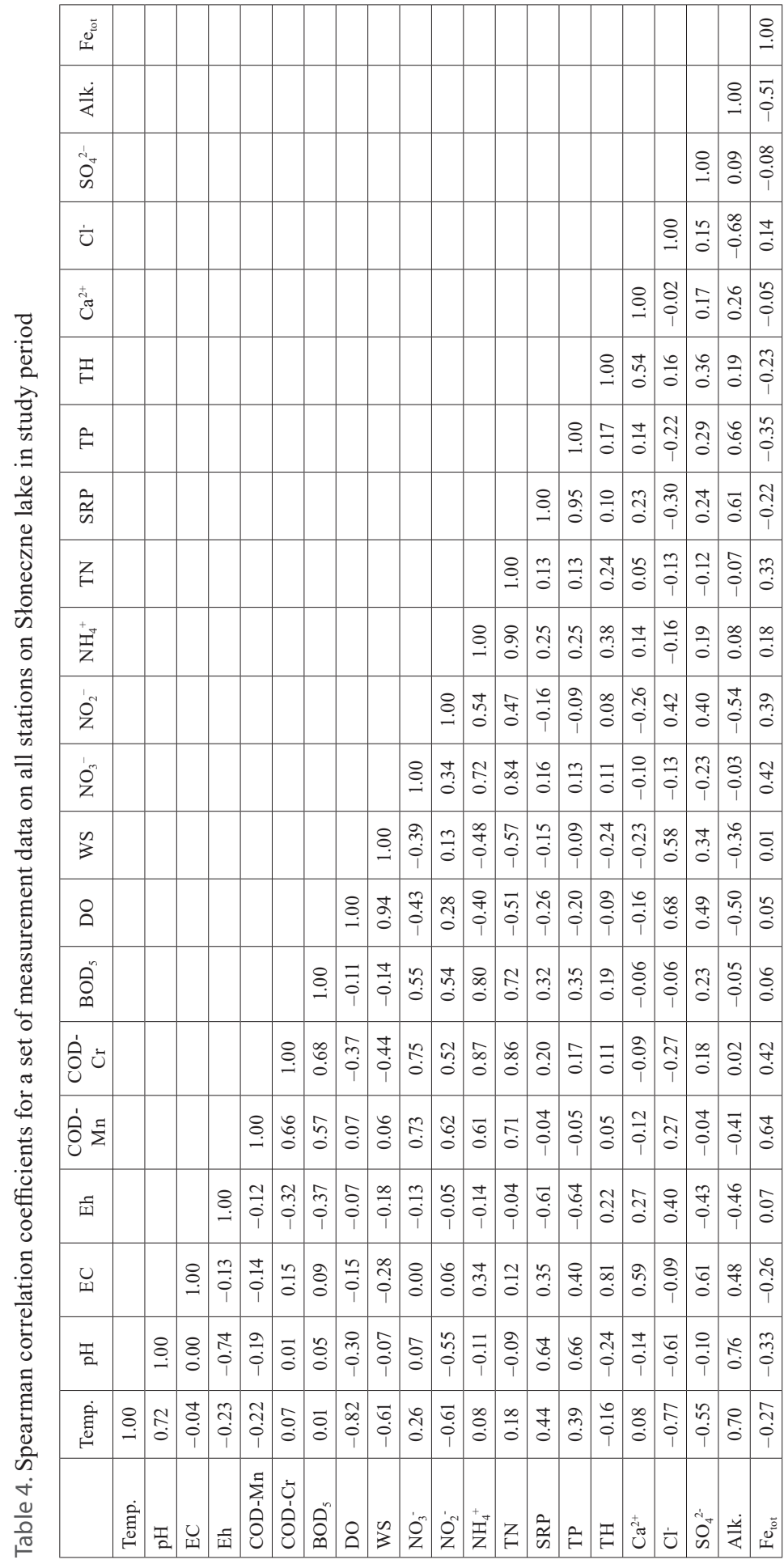


solar lake was shaped by the redox pair $\mathrm{NO}_{3}{ }^{-} / \mathrm{NH}_{4}{ }^{+}$, as a result of the data on concentration values mentioned above ions (Schuring et al., 2000).

The factor analysis presented in Tables 5-7 shows that indices whose variability in a statistically significant way - as the studies showed - characterize the variability of water in the examined tank were: TEMP, $\mathrm{pH}, \mathrm{EC}$, Eh, COD-Cr, DO, WS, $\mathrm{NO}_{3}^{-}, \mathrm{NH}_{4}^{+}, \mathrm{TN}, \mathrm{SRP}, \mathrm{TP}, \mathrm{TH}, \mathrm{Cl}^{-}$.

Table 5. Factor Analysis for Słoneczne Lake in study period

\begin{tabular}{|c|c|c|c|c|}
\hline Indices & VF1 & VF2 & VF3 & VF4 \\
\hline Temp & 0.9262 & 0.0022 & 0.2791 & 0.1989 \\
\hline $\mathrm{pH}$ & 0.4792 & -0.1996 & 0.2543 & 0.7803 \\
\hline $\mathrm{EC}$ & 0.0379 & 0.2483 & -0.7814 & 0.4756 \\
\hline Eh & 0.0295 & -0.0971 & -0.1553 & -0.8795 \\
\hline COD-Mn & -0.6772 & 0.3614 & 0.5566 & 0.1422 \\
\hline COD-Cr & 0.1391 & 0.8895 & 0.0877 & -0.1876 \\
\hline $\mathrm{BOD}_{5}$ & -0.2834 & 0.6892 & -0.1594 & 0.3713 \\
\hline DO & -0.9306 & -0.3244 & 0.0597 & 0.0196 \\
\hline WS & -0.7394 & -0.5331 & 0.2049 & 0.1522 \\
\hline $\mathrm{NO}_{3}^{-}$ & 0.0769 & 0.7726 & 0.5218 & 0.0013 \\
\hline $\mathrm{NO}_{2}^{-}$ & -0.3273 & 0.6186 & 0.1673 & -0.3187 \\
\hline $\mathrm{NH}_{4}^{+}$ & 0.0134 & 0.8732 & -0.3630 & 0.0493 \\
\hline $\mathrm{TN}$ & 0.1507 & 0.9683 & 0.0215 & 0.0369 \\
\hline SRP & 0.3621 & 0.0404 & -0.1631 & 0.7901 \\
\hline $\mathrm{TP}$ & 0.3348 & 0.0134 & -0.2543 & 0.8140 \\
\hline $\mathrm{TH}$ & -0.1665 & 0.2508 & -0.8735 & -0.0452 \\
\hline $\mathrm{Ca}^{2+}$ & 0.0240 & 0.1496 & -0.6986 & 0.0545 \\
\hline $\mathrm{Cl}^{-}$ & -0.8729 & 0.0364 & -0.0871 & -0.1664 \\
\hline $\mathrm{SO}_{4}{ }^{2-}$ & -0.4090 & 0.0029 & -0.6964 & 0.3736 \\
\hline Alkalinity & 0.6150 & -0.1749 & -0.2232 & 0.6444 \\
\hline $\mathrm{Fe}_{\mathrm{tot}}$ & -0.3100 & 0.3320 & 0.5251 & -0.0703 \\
\hline $\mathrm{T} 1$ & -0.7965 & 0.0507 & 0.5342 & 0.1214 \\
\hline $\mathrm{T} 2$ & -0.3013 & 0.0315 & -0.6636 & -0.2545 \\
\hline $\mathrm{T} 3$ & -0.0486 & -0.1413 & -0.4296 & 0.3683 \\
\hline $\mathrm{T} 4$ & 0.2874 & 0.0260 & 0.1880 & -0.7893 \\
\hline T5 & 0.3599 & -0.0750 & 0.1658 & 0.0756 \\
\hline T6 & 0.4990 & 0.1080 & 0.2052 & 0.4785 \\
\hline S1 & 0.0134 & 0.9354 & -0.0752 & 0.0142 \\
\hline $\mathrm{S} 2$ & -0.0131 & -0.3581 & 0.0187 & 0.0065 \\
\hline S3 & -0.0002 & -0.5773 & 0.0565 & -0.0207 \\
\hline
\end{tabular}

In summary, based on the collected data from the first half of the year 2015, it was stated that in the Słoneczne Lake self-purification processes based on sedimentation of suspensions, changes in concentrations of suspended and dissolved organic matter related to oxidation of organic matter 
and changes were documented in this work. The redox potential of the studied waters, which only became apparent after the water has reached the outflow area of the lake.

Table 6. Eigenvalues for factor analysis conducted after varimax rotation Słoneczne Lake in study period for all sampling stations

\begin{tabular}{|c|c|c|c|c|}
\hline No. & Eigenvalue & Per cent total variation & Cumulated Eigenvalue & $\begin{array}{c}\text { Cumulated per cent } \\
\text { of total variance }\end{array}$ \\
\hline 1 & 6.667039 & 22.22346 & 6.66704 & 22.22346 \\
\hline 2 & 6.345121 & 21.15040 & 13.01216 & 43.37387 \\
\hline 3 & 5.176954 & 17.25651 & 18.18911 & 60.63038 \\
\hline 4 & 3.821286 & 12.73762 & 22.01040 & 73.36800 \\
\hline
\end{tabular}

Table 7. Results of the validity test of the use of FA for selected water quality indices of Słoneczne Lake

\begin{tabular}{|l|l|c|}
\hline \multicolumn{2}{|l|}{ Kaisera-Mayer-Olkin } & 0.6430 \\
\hline \multirow{3}{*}{ Bartlett's Sphericity test } & Chi-square & 383 \\
\cline { 2 - 3 } & df & 136 \\
\cline { 2 - 3 } & Significance level & 0.0001 \\
\hline
\end{tabular}

Thus, in the study period Słoneczne Lake was a settling pond and relatively efficiently operating biological pond for water Bukowa stream flowing through the Słoneczne reservoir.

\section{Conclusions}

1. The quality of water flowing through the Słoneczne Lake during the research period, i.e. January to June 2015, improved to a certain extent - along the course of the lake's water flow, especially between station S1 (Bukowa river inflow area to the lake) and the station S2 (center of the lake). However, the quality of the tested waters according to the official lake quality assessment criteria - which should be used for the assessment of the quality of the waters of the Słoneczne Lake was III or lower quality class at all measurement points due to the high values of total phosphorus concentrations in the waters.

2. Słoneczne Lake during the research period acted as a settling pond and a biological pond, especially the zone from the inflow area to central part of the lake, where suspended sedimentation and oxidation of suspended and dissolved organic matter occurred, and these effects were quantitatively assessed as moderate. 


\section{Literature}

Affum, A.O., Osae, S.D., Nyarko, B.J.B., Afful, S., Fianko, J.R., Akiti, T.T., Adomako, D. (2015). Total coliforms, arsenic and cadmium exposure through drinking water in the Western Region of Ghana: application of multivariate statistical technique to groundwater quality. Environ Monit Assess., 2 (187), 1-23. DOI: 10.1007/s10661-014-4167-x.

Angyal, Z., Sárközi, E., Gombás, Á., Kardos, L. (2016). Effects of land use on chemical water quality of three small streams in Budapest. O Geosci., 1 (8), 133-142. DOI: https://doi.org/10.1515/geo-20160012 .

APHA (2012). Standard methods for examination of water and wastewater, $16^{\text {th }} \mathrm{ed}$. Washington.

Badillo-Camacho, J., Reynaga-Delgado, E., Barcelo-Quintal, I., del Valle, P.F.Z., López-Chuken, U.J., Orozco-Guareño, E. (2015). Water quality assessment of a tropical Mexican lake using multivariate statistical techniques. J Environ Protect. 3 (6), 215. DOI: 10.4236/jep.2015.63022.

Białecki, T., Turek-Kwiatkowska, L. (1991). Szczecin stary i nowy. Encyklopedyczny zarys historycznych dzielnic i osiedli oraz obiektów fizjograficznych miasta. Szczecin: Wyd. STK.

Chow, M.F., Shiah, F.K., Lai, C.C., Kuo, H.Y., Wang, K.W., Lin, C.H, Ko, C.Y. (2016). Evaluation of surface water quality using multivariate statistical techniques: a case study of Fei-Tsui Reservoir basin, Taiwan. Environ Eart Sci. 1 (75), 6. DOI: 10.1007/s12665-015-4922-5.

Gao, H., Song, Lv.C., Zhang, Y., Zheng, Y., Wen, L.Y., Yu, H. (2015). Chemometrics data of water quality and environmental heterogeneity analysis in Pu River, China. Environ Earth Sci., 9 (73), 5119-5129. DOI: $10.1007 / \mathrm{s} 12665-015-4233-\mathrm{x}$.

Gutchess, K., Jin, L., Lautz, L., Shaw, S.B., Zhou, X., Lu, Z. (2016). Chloride sources in urban and rural headwater catchments, central New York. Sci Tot Environ., 565, 462-472. DOI: 10.1016/j.scitotenv.2016.04.181.

Hill, M.J., Biggs, J., Thornhill, I., Briers, R.A., Gledhill, D.G., White, J.C., Hassall, C. (2017). Urban ponds as an aquatic biodiversity resource in modified landscapes. Glob Change Boil., 3 (23), 986-999. DOI: 10.1111/gcb.13401.

Hłyńczak, A., Baranowska-Bosiacka, I., Janeczko, A. (1998). Występowanie niektórych metali ciężkich w wybranych zbiornikach wodnych Szczecina. Archiwum Ochrony Środowiska, 1 (24), 57-67.

Huser, B.J., Futter, M., Lee, J.T., Perniel, M. (2016). In-lake measures for phosphorus control: The most feasible and cost-effective solution for long-term management of water quality in urban lakes. Wat Res., 97, 142-152. DOI: 10.1016/j.watres.2015.07.036.

Kazi, T.G., Arain, M.B., Jamali, M.K., Jalbani, N., Afridi, H.I., Sarfraz, R.A. (2009). Assessment of water quality of polluted lake using multivariate statistical techniques: A case study. Ecotox Environ Safety, 2 (72), 301-309. DOI: 10.1016/j.econenv.2008.02.024.

Kumar, A.S., Reddy, A.M., Srinivas, L., Reddy, P.M. (2014). Assessment of surface water quality in hyderabad lakes by using multivariate statistical techniques, Hyderabad - India. Environ Pollut., 2 (4), 14-23. DOI: 10.5539/ep.vn2p14.

Kumarasamy, P., James, R.A., Dhams, H.U., Byeon, C.W., Ramesh, R. (2014). Multivariate water quality assesment for the Tamiraparani river basin, Southern India. Environ Earth Sci., 71, 2241-2451. DOI: 10.1007/s12665-013-2644-0.

Li, D., Huang, D., Guo, C., Guo, X. 2015. Multivariate statistical analysis of temporal-spatial variations in water quality of a constructed wetland purification system in a typical park in Beijing, China. Environ Monit Assess., 1 (187), 1-14. DOI: 10.1007/s10661-014-4219-2. 
Loganathan, G., Krishnaraj, S., Muthumanickam, J. (2015). Chemometric and trend analysis of water quality of the South Chennai lakes: an integrated environmental study. J Chemometr., 29, 59-68. DOI: 10.1002/cem.2664.

Miller, T., Svobodova, Z., Meller, E., Poleszczuk, G. (2016). Glebokie Lake in Szczecin after hydrotechnical regulations. Ecol Chem Eng S., 1 (23), 71-86. DOI: 10.1515/eces-2016-0005.

Mustapha, A., Aris, A.Z., Juahir, H., Raml, M.F., Kura, N.U. (2013). River water quality assessment using environmentric techniques: case study of Jakara River Basin. Environ Sci Pollut Res, 8 (20), 5630-5644. DOI: 10.1007/s11356-013-1542-z.

Najar, I.A., Khan, A.B. (2012). Assessment of water quality and identification of pollution sources of three lakes in Kashmir, India, using multivariate analysis. Environ Earth Sci, 8 (66), 2367-2378. DOI: 10.1007/s12665-011-1458-1.

Niedźwiecki, E., Wojcieszczuk, T., Poleszczuk, G., Meller, E., Malinowski, R., Sammel, A. (2007). Skład chemiczny osadów dennych zbiorników wodnych Rusałka i Słoneczne aglomeracji szczecińskiej i możliwości ich wykorzystania. Zesz. Probl. Post. Nauk Roln., 520, 353-362.

Olguín, E.J., Sánchez-Galván, G., Melo, F.J., Hernández, V.J., González-Portela, R.E. (2017). Long-term assessment at field scale of Floating Treatment Wetlands for improvement of water quality and provision of ecosystem services in a eutrophic urban pond. Sci Total Environ, 584, 561-571. DOI: 10.1016/j. scitotenv.2017.01.072.

Regulation (2016). Rozporządzenie Ministra Środowiska z dnia 21 lipca 2016 r. w sprawie sposobu klasyfikacji stanu jednolitych części wód powierzchniowych oraz środowiskowych norm jakości dla substancji priorytetowych (Dz.U. poz. 1187).

Schüring, J., Schulz, H.D., Fischer, W.R., Böttcher, J., Duijnisveld, W.H.M. (2000). Redox. Fundamentals, Processes and Applications. Heidelberg: Springer. DOI: 10.1007/978-3-662-04080-5.

Singh, S.K., Singh, P., Gautam, S.K. (2016). Appraisal of urban lake water quality through numerical index, multivariate statistics and earth observation data sets. Int J Environl Sci Tech, 2 (13) 445-456. DOI: 10.1007/s13762-015-0850-x.

Song, K., Winters, C., Xenopoulos, M.A., Marsalek, J., Frost, P.C. (2017). Phosphorus cycling in urban aquatic ecosystems: connecting biological processes and water chemistry to sediment $\mathrm{P}$ fractions in urban stormwater management ponds. Biogeochem, 1-2 (132) 203-212. DOI: 10.1007/s10533-0170293-1.

Tadajewski, A., Rutkowski, D. (1993). Stan wód jezior Szczecina i okolic oraz kanałów i basenów Portu Szczecińskiego. In: J. Jasnowska (ed.). Stan środowiska miasta i rejonu Szczecina (pp. 205-218). ESOFT.

Taoufik, G., Khouni, I., Ghrabi, A. (2017). Assessment of physic-chemical and microbiological surface water quality using multivariate statistical techniques: a case study of the Wadi El-Bey River. Tunisia. Arab J Geosci, 10, 181. DOI: 10.1007/s12517-017-2898-z.

Wang, Y., Wang, P., Bai, Y., Tian, Z., Li, J., Shao, X., Mustavich, L.F. (2013). Assessment of surface water quality via multivariate statistical techniques: A case study of the Songhua River Harbin region, China. J Hydr Environ Res, 1 (7), 30-40. DOI: 10.1016/jher.2012.10.003.

Cite as: Miller, T., Drozdowska, A., Zawal, A., Poleszczuk, G. (2017). Water quality and ecological role of urban lake: a case study of Słoneczne Lake in Szczecin (NW-Poland). Acta Biologica, 24, 57-72. DOI: 10.18276/ab.2017.24-07. 